\title{
Analysis for Materials Test Reactor (MTR Fuel Assemblies in Dry Storage)
}

by

R. F. Miller

Westinghouse Savannah River Company

Savannah River Site

Aiken, South Carolina 29808

R. L. Sindelar

This paper was prepared in connection with work done under the above contract number with the U. S. Department of Energy. By acceptance of this paper, the publisher and/or recipient acknowledges the U. S. Government's right to retain a nonexclusive, royalty-free license in and to any copyright covering this paper, along with the right to reproduce and to authorize others to reproduce all or part of the copyrighted paper. 


\section{DISCLAIMER}

This report was prepared as an account of work sponsored by an agency of the United States Government. Neither the United States Government nor any agency thereof, nor any of their employees, makes any warranty, express or implied, or assumes any legal liability or responsibility for the accuracy, completeness, or usefulness of any information, apparatus, product, or process disclosed, or represents that its use would not infringe privately owned rights. Reference herein to any specific commercial product, process, or service by trade name, trademark, manufacturer, or otherwise does not necessarily constitute or imply its endorsement, recommendation, or favoring by the United States Government or any agency thereof. The views and opinions of authors expressed herein do not necessarily state or reflect those of the United States Govemment or any agency thereof.

This report has been reproduced directly from the best available copy.

Available to DOE and DOE contractors from the Office of Scientific and Technical Information, P.O. Box 62, Oak Ridge, TN 37831; prices available from (615) 576-8401.

Available to the public from the National Technical Information Service, U.S. Department of Commerce, 5285 Port Royal Road, Springfield, VA 22161. 


\section{DISCLAIMER}

Portions of this document may be illegible in electronic image products. Images are produced from the best available original document. 


\title{
Creep Analysis for Materials Test Reactor (MTR) Fuel Assemblies in Dry Storage (U)
}

\author{
R. F. Miller and R. L. Sindelar
}

\section{April 1995}

DOES NOT CONTAIN UNCLASSIFIED CONTROLLED NUCLEAR INFORMATION

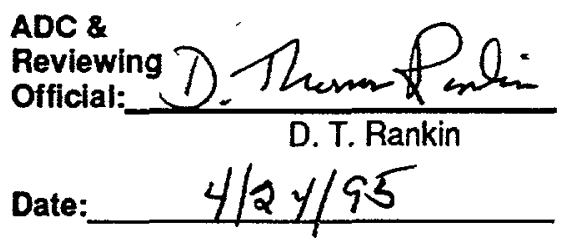

Westinghouse Savannah River Company P. O. Box 616 Aiken, SC 29802

PREPARED FOR THE U.S. DEPARTMENT OF ENERGY UNDER CONTRACT DE-AC09-89SR18035 


\title{
ASET
}

APPLIED SCIENCE \& ENGINEERING TECHNOLOGY

Keywords: Aluminum

Uranium

Aluminum-Uranium Alloys

Creep

Spent Nuclear Fuel

Retention - Permanent

\section{Creep Analysis for Materials Test Reactor (MTR) \\ Fuel Assemblies in Dry Storage (U)}

\author{
By \\ fFm \\ R. F. Miller and R. L. Sindelar
}

April 1995 
DOCUMENT:

TITLE:

TASK:
WSRC-TR-95-0121

CREEP ANALYSIS FOR MATERIALS TEST REACTOR (MIR) FUEL ASSEMBLIES IN DRY STORAGE (U)

WSRC-RP-94-360, REV. 1

APPROVALS

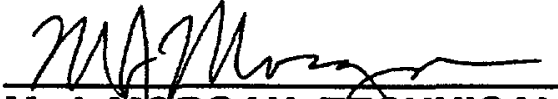

M. J. MORGAN, TE MATERIALS TECHNOLOGY SECTION

J. R. MURPHY, CUSTOMER REVIEW MATERIALS TECHNOLOGY SECTION

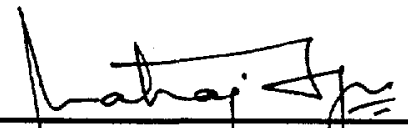

N.C. IYER, MANAGEMENT REVIEW MATERIALS TECHNOLOGY SECTION

T. L. CAPELETTI, MANAGEMENT REVIEW MATERIALS TECHNOLOGY SECTION
DATE: $\quad 4 / 24 / 95$

DATE: $\quad 4 / 25 / 45$

DATE: $\quad 5 / 4195$

DATE: $5 / 8 / 95$ 
DOCUMENT: $\quad$ WSRC-TR-95-0121

TITLE:

CREEP ANALYSIS FOR MATERIALS TEST REACTOR (MTR) FUEL ASSEMBLIES IN DRY STORAGE (U)

\section{TABLE OF CONTENTS}

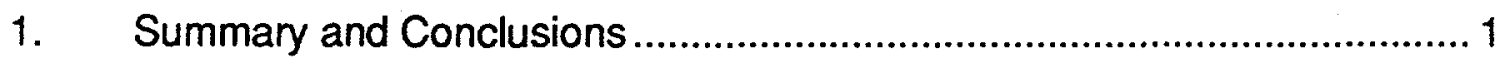

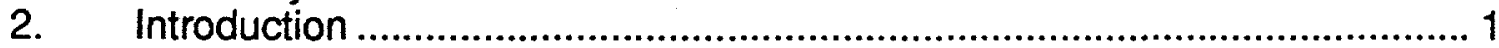

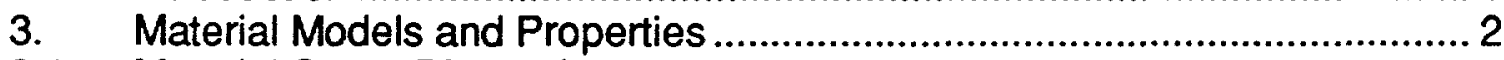

3.1 Material Creep Discussion ................................................................ 3

3.2 Experimental Creep Data from Literature ............................................... 6

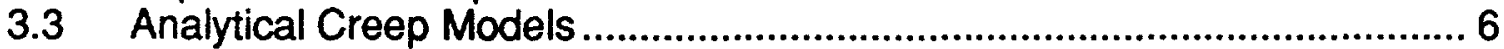

3.4 Other Material Property Data .....................................................................

4. Finite Element Stress and Creep Analysis ............................................. 9

4.1 MTR Fuel Element Model Description ..................................................... 10

4.2 Model Loading and Boundary Conditions ............................................ 11

4.3 Finite Element Analysis Results .......................................................... 11

4.4 Creep and Deformation Estimate for MTR Fuel .................................... 12

5. Comparison to a Similar Creep Analysis .............................................. 13

5.1 INEL Creep Data and Fuel Element Model ............................................. 14

6. Application of Coble Creep Model to Experimental Data............................ 17

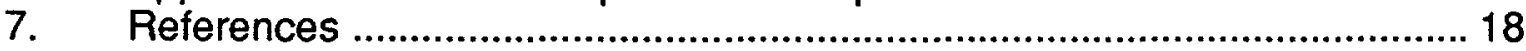

\section{LIST OF FIGURES}

Figure 1 - MTR Nuclear Fuel Simplified Schematic ......................................... 2

Figure 2 - Typical Form of the Creep Curve for Metals .................................. 3

Figure 3 - Deformation Mechanism Map for Pure Aluminum, $10 \mu \mathrm{m}$ Grain Size . 5

Figure 4 - Deformation Mechanism Map for Pure Aluminum, $1 \mathrm{~mm}$ Grain Size ... 5

Figure 5 - Finite Element Model of MTR Fuel Element ..................................... 10

Figure 6 - Maximum Deflection vs. Fuel Temperature ........................................ 14

Figure 7 - Optical Micrographs of MTR Fuel Cladding Cross-Section................... 15

Figure 8 - ORNL Creep Data for Al $6061-0$ at $250^{\circ} \mathrm{C}\left(482^{\circ} \mathrm{F}\right)$............................. 16

\section{LIST OF TABLES}

Table 1 - Material Parameters for Creep Constitutive Relationships.................... 8

Table 2 - Material Properties of Al 1100 and U-Al for ABAQUS Input ................... 9

Table 3 - Comparison of Coble Creep Model to Experimental Data ...................... 18 


\section{Summary and Conclusions}

This report documents a creep analysis to estimate the maximum acceptable temperature for spent aluminum clad nuclear fuels in dry storage. The limiting temperature is that at which excessive creep occurs in the materials of the fuel elements. Excessive creep could result in cladding rupture or in unacceptable risk of nuclear criticality as the fissile material storage configuration is altered. The results indicate that MTR spent fuel assemblies can be at a temperature of $200^{\circ} \mathrm{C}\left(392^{\circ} \mathrm{F}\right)$ for up to 50 years without exceeding 0.1 inch displacement due to material creep.

The majority of aluminum clad fuels from foreign research reactors (FRR) and domestic research reactors (DRR) are of the materials test reactor (MTR) design $[1,2]$. The focus of this effort was to develop a methodology to predict creep response of MTR fuels and to establish the maximum fuel/cladding temperature for the MTR fuel to avoid excessive creep deformation. Excessive creep deformation is assumed to be fuel plate displacement of 0.1 ". The creep strains associated with this deformation are well below rupture strains. Deformation due to creep strain is dependent on specific geometry and material considerations. Other aluminum-based fuel designs could be individually analyzed using the methodology described in this report to estimate their specific creep deformation.

\section{Introduction}

The design of dry storage facilities for aluminum clad spent nuclear fuel assemblies must consider the decay heat generated by the fuel assemblies for a fifty year interim storage period. The maximum temperature the fuels will be allowed to reach will be determined by the limiting material degradation mechanism. Limiting degradation mechanisms are those that lead to gross rupture of the fuel element claddings or to gross distortion (slump) of the fuels. Degradation of aluminum-clad fuels in dry storage environments is currently being addressed in an analytical and testing program [3]. A potentially limiting degradation mechanism is material creep. Over time-even at low stress levelsmaterials exposed to high temperature can experience creep strain leading to fuel deformation or to rupture of the cladding or to both. The separation distances between fuel assemblies in the storage facility is specified so that nuclear criticality will not occur in the as-designed configuration. Large creep strains could potentially alter the storage configuration. Similarly, creep rupture would violate the condition of having the cladding serve as the primary confinement barrier. In order to avoid creep rupture or large deformations of the fuel assemblies, the operating temperature of the facility must be kept at or below temperatures that would result in significant material creep. 
The current dry storage plan calls for the ability to store many different fuel assembly designs [4]. The largest percentage of aluminum-clad fuels to be stored at SRS [2], approximately 70\%, will be the materials test reactor (MTR) fuel type $[1,2,4]$. For that reason, MTR fuel was chosen as prototypic in this analysis. The conclusions reported in this document should apply broadly to other designs to be stored in the facility and are presented such that, with only simple analysis based on storage configuration, they too could be qualified for storage.

Figure 1 shows a simplified schematic of the MTR design. Eighteen curved plates consisting of aluminum clad fuel are contained in each assembly. The only applied loading on the assemblies is due to gravity. Finite element analysis was used to approximate the stress in the fuel assemblies for different storage orientations. The finite element code ABAQUS v5.4-1 was used to make the calculations. The bulk of this memorandum describes the development of the material properties and modeling techniques that were used to estimate the creep strains.
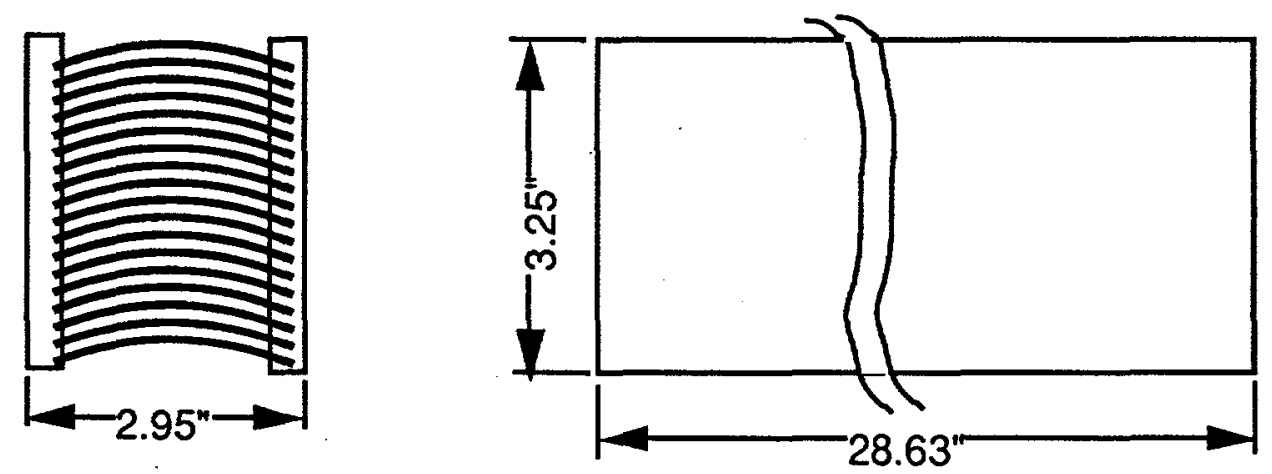

- fuel element radius of curvature $=5.5^{\prime \prime}$

- fuel element total thickness $=0.05^{\mathrm{m}}$

- fuel cladding $=0.01^{\prime \prime}$ minimum

- fuel element circumferential width $=2.78^{\prime \prime}$

Note: This depicts simplified geometry neglecting support structure etc.

Figure 1 - MTR Nuclear Fuel Simplified Schematic [5]

\section{Material Models and Properties}

Material creep is defined as "...the time-dependent and permanent deformation of materials when subjected to a constant load or stress" [6]. Actually, this definition is somewhat limiting in that creep can occur under conditions of varying stress as well. This section describes the 
development of the material property data used in the analysis to predict the creep behavior of the MTR spent fuel in the dry storage condition.

\subsection{Material Creep Discussion}

For metallic materials, creep generally only becomes important for temperatures greater than $0.4 \mathrm{~T}_{\mathrm{m}}$ where $\mathrm{T}_{\mathrm{m}}$ is the absolute melting temperature [6]. In an engineering sense, creep typically exhibits the behavior graphically depicted in Figure 2. The total strain is the sum of any instantaneous elastic and instantaneous plastic plus time-dependent plastic (creep) strains. Here the primary or transient creep phase is followed by the secondary or steady-state creep phase. If allowed to proceed long enough, the tertiary phase is distinguished by the accelerated pace of deformation that eventually ends in creep rupture.

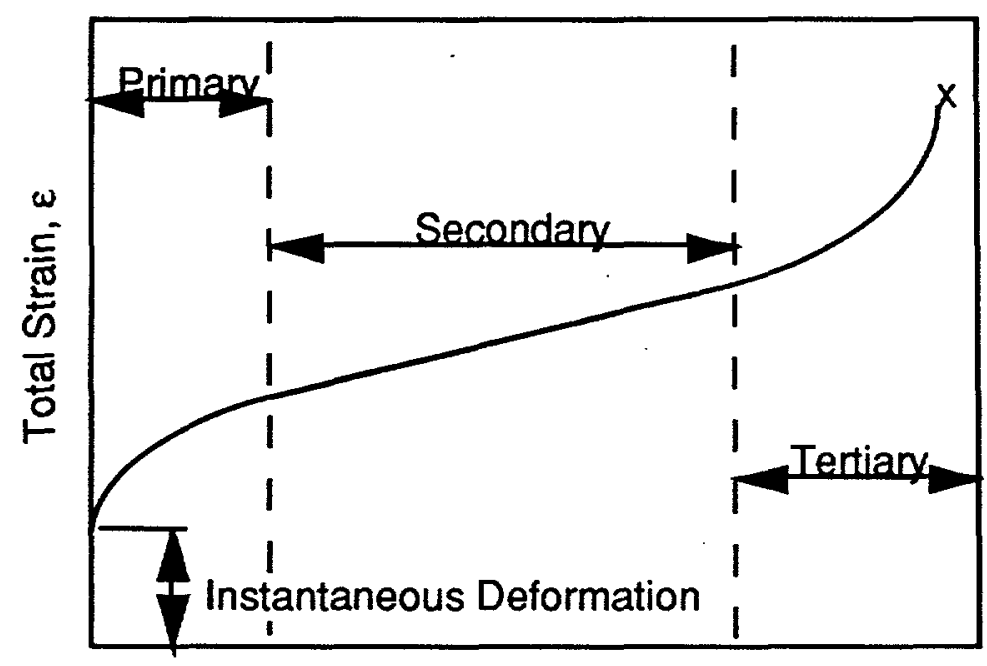

Time, $t$

Figure 2 - Typical Form of the Creep Curve for Metals [7]

Creep in a material is the net result of one or more microstructural deformation mechanisms. Dislocation glide is the most important mechanism of plastic deformation [6]. At low homologous temperatures, dislocation glide due to high stress application generally leads to an increase in dislocation density and a corresponding increase in flow stress with accumulated strain (strain hardening). At higher homologous temperatures (typically above 0.4 for metals) dynamic recovery can take place in the material thereby negating the strain hardening effect that occurs at low homologous temperatures. Many mechanisms can be responsible for dynamic recovery but the most common is dislocation annihilation that prevents the increase in dislocation density. 
Apart from plastic deformation due to dislocation migration, other mechanisms can contribute to the overall effect termed creep. Diffusion-either through the lattice or across grain boundaries-can lead to irreversible deformation of the material. Reference 6 states that "Until recently [1988], it was thought that diffusional creep can take place only at very high homologous temperatures (higher than 0.95) and very low stresses (less than $10^{-6} \mathrm{G}$ ) [shear modulus]. Consequently, its significance for engineering practice is limited. However, this view has had to be revised in the last decade since it has been recognized that at creep rates ranging from 10-12 to $10^{-10} \mathrm{~s}^{-1}$, diffusional creep may dominate over dislocation creep even at homologous temperatures close to 0.5." This helps explain the absence of test data for lowstress, intermediate-temperature conditions in the published literature. If maintained, however, creep rates of $10^{-10} \mathrm{~s}^{-1}$ would produce creep strains of $\sim 16 \%$ in fifty years.

Lattice diffusion (Nabarro-Herring creep) takes place at relatively high homologous temperature $\left(>0.8 \mathrm{~T}_{\mathrm{m}}\right)$ and low normalized shear stress $\left(<10^{-4} \sigma / \mathrm{G}\right)$ whereas grain boundary diffusion (Coble creep) occurs typically at relatively low homologous temperature and low normalized shear stress [8]. Also, under certain conditions of very high stress or temperature, grain boundary sliding can contribute to overall creep. All these deformation mechanisms contribute to some degree the sum of time-dependent plastic strain which is measured indirectly in a creep test. Reference 6 states that, generally, plastic deformation in a creep regime is the sum of damage due to the following mechanisms:

$$
\varepsilon_{\mathrm{pl}}=\varepsilon_{\mathrm{dg}}+\varepsilon_{\mathrm{n}}+\varepsilon_{\mathrm{gb}}+\varepsilon_{\mathrm{d}}+\varepsilon_{\mathrm{v}}
$$

Where:

$$
\begin{aligned}
& \varepsilon_{\mathrm{pl}}=\text { total plastic strain } \\
& \varepsilon_{\mathrm{dg}}=\text { strain due to dislocation glide } \\
& \varepsilon_{\mathrm{n}}=\text { strain due to non-conservative motion of dislocations } \\
& \varepsilon_{\mathrm{gb}}=\text { strain due to grain boundary sliding } \\
& \varepsilon_{\mathrm{d}}=\text { strain due to stress directed diffusion of vacancies } \\
& \varepsilon_{\mathrm{v}}=\text { strain due to intercrystalline void nucleation and growth }
\end{aligned}
$$

Though all the mechanisms contribute to overall plastic deformation, typically, one mechanism will dominate. Figures 3 and 4 show deformation mechanism maps for pure aluminum with a grain size of $10 \mu \mathrm{m}$ and $1 \mathrm{~mm}$ respectively [8]. Clearly, grain size is an important factor when determining the diffusion creep rate in low stress regimes. The deformation maps plot normalized shear stress (applied stress over shear modulus) versus homologous temperature (applied temperature over melt temperature in Kelvin). Superimposed on these plots are lines of constant strain rate. One can simply calculate the two normalized values and reference the creep rate graphically for an estimate of creep rate. As previously mentioned, all the deformation mechanisms are in effect but one typically will dominate. The deformation mechanism maps provide an 
assessment of which mechanism will dominate overall creep. Except for values falling in the breakdown region of power law creep or near the boundaries of two mechanisms, only the primary mechanism need be considered without incurring unacceptable error [6].

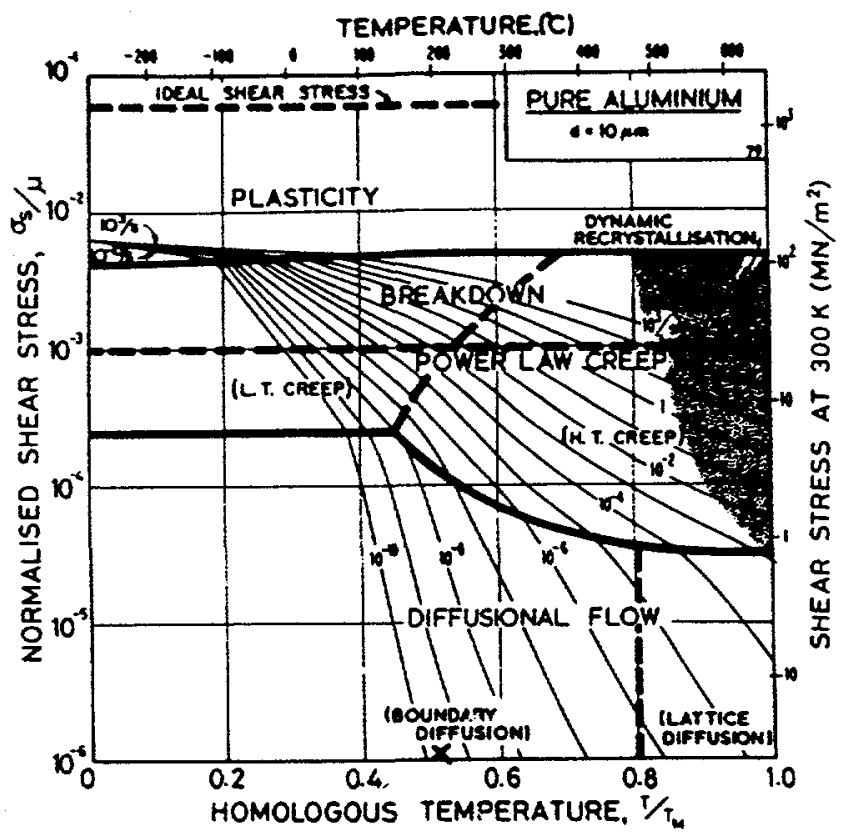

Figure 3 - Deformation Mechanism Map for Pure Aluminum, $10 \mu \mathrm{m}$ Grain Size [8]

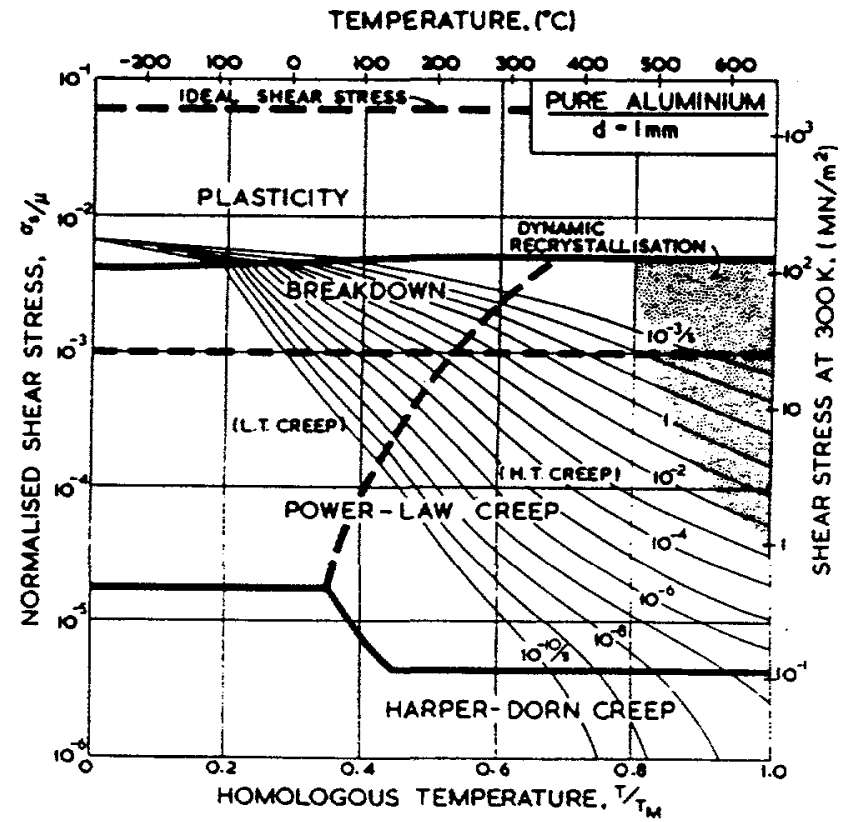

Figure 4 - Deformation Mechanism Map for Pure Aluminum, $1 \mathrm{~mm}$ Grain Size [8] 


\subsection{Experimental Creep Data from Literature}

A considerable amount of research has been conducted on creep of structural materials and is available in published literature. Typically, however, relative to the conditions of dry fuel storage, the data are for either high stress or high temperature conditions or both. Because of the dearth of test data in the stress and temperature ranges of interest, reasonable extrapolation of available data or reliance on a theoretical approach is required for creep life predictions.

\subsection{Analytical Creep Models}

As previously described, the summary of conditions called material creep is really a blanket term for the observed effect of several different typically microscopic deformation mechanisms. The major mechanisms and commonly used models for predicting steady-state creep in these regimes are described in this section.

Power Law Creep - This is a general term that encompasses the most familiar creep mechanisms that occur at relatively high stress and temperature. Fundamentally, under load, dislocations within the metallic grains migrate leading to increasing irreversible deformation with time. Equation 2 depicts the common model for power law creep [7].

$$
\dot{\varepsilon}_{\mathrm{pl}}^{\mathrm{cr}}=A \sigma^{\mathrm{n}}
$$

Where: $\quad \dot{\varepsilon}_{\mathrm{pl}}^{\mathrm{cr}}=$ strain rate due to power law strain

$A=$ power law creep coefficient

$\sigma=$ applied stress

$\mathrm{n}=$ empirically determined stress exponent

A very useful reference for aluminum creep develops the value of " $A$ " in equation (2) and provides a table of values for determining creep rate [9]. Equation (3) is an expanded representation of equation (2) provided in reference 9 that has a functional dependence on temperature among other parameters. Equation (4) is applicable in the high temperature dislocation climb creep regime whereas equation (3) represents low temperature dislocation climb creep regime. The parameter definitions and values for pure aluminum in Table 1 are found on page 9 of this document.

$$
\begin{aligned}
& \dot{\varepsilon}_{\mathrm{lt}}^{\mathrm{cr}}=50 \mathrm{~A}_{1} \mathrm{D}_{\mathrm{o}(\mathrm{c})} \exp \left(\frac{\mathrm{Q}_{\mathrm{c}}}{\mathrm{RT}}\right)\left(\frac{\mathrm{G} \cdot \mathrm{b}}{\mathrm{k} \cdot \mathrm{T}}\right)\left(\frac{\sigma}{\mathrm{G}}\right)^{\mathrm{n}+2} \\
& \dot{\varepsilon}_{\mathrm{ht}}^{\mathrm{cr}}=\mathrm{A}_{1} \mathrm{D}_{\mathrm{o}(1)} \exp \left(\frac{-\mathrm{Q}_{\mathrm{c}}}{\mathrm{RT}}\right)\left(\frac{\mathrm{G} \cdot \mathrm{b}}{\mathrm{k} \cdot \mathrm{T}}\right)\left(\frac{\sigma}{\mathrm{G}}\right)^{\mathrm{n}}
\end{aligned}
$$


Harper-Dorn Creep - Another possible creep mechanism at low normalized stresses in Harper-Dorn creep. Judging from the literature discussion, this mechanism is complex and not fully understood at this time [6]. Harper-Dorn creep is described as dislocation based but exhibits some characteristics of diffusional creep (i.e. linear dependence of creep rate on stress.) However, unlike diffusion creep mechanisms, Harper-Dorn creep rate is not dependent on grain size. Traditionally, Harper-Dorn creep was thought to occur at homologous temperatures above $\sim 0.95$ and only with large grain sizes. More recently, Harper-Dorn creep has been observed in several materials at homologous temperatures in the range of 0.35 to 0.60 , applied stresses up to $9 \times 10^{-5} \mathrm{G}$ and for grain sizes considerably smaller than $500 \mu \mathrm{m}$ [6]. Harper-Dorn creep rate is described by equation (5) [9].

$$
\dot{\varepsilon}_{\mathrm{HD}}^{\mathrm{cr}}=\mathrm{A}_{\mathrm{HD}} \mathrm{D}_{\mathrm{o}(\mathrm{l})} \exp \left(\frac{-\mathrm{Q}_{1}}{\mathrm{RT}}\right)\left(\frac{\mathrm{G} \cdot \mathrm{b}}{\mathrm{k} \cdot \mathrm{T}}\right)\left(\frac{\sigma}{\mathrm{G}}\right)
$$

Lattice Diffusion Creep - There are two predominant diffusion mechanisms for creep. One is diffusion within the lattice of a crystal or Nabarro-Herring creep. This mechanism predominates for small grained material at relatively low stress and high temperature. The expanded Nabarro-Herring creep rate is expressed as equation 6 [9].

$$
\dot{\varepsilon}_{\mathrm{nh}}^{\mathrm{cr}}=A_{N H} D_{o(1)} \exp \left(\frac{-Q_{1}}{R T}\right)\left(\frac{G \cdot b}{k \cdot T}\right)\left(\frac{b}{d}\right)^{2}\left(\frac{\sigma}{G}\right)
$$

Grain Boundary Diffusion Creep - The second major type of diffusional creep is grain boundary diffusion or Coble creep. Coble creep predominates when grain size is small and temperatures are low compared to Nabarro-Herring creep. Coble creep is described by equation 7 [9].

$$
\dot{\varepsilon}_{C o}^{c r}=A_{C o} D_{o(g b)} \exp \left(\frac{Q_{g b}}{R T}\right)\left(\frac{G \cdot b}{k \cdot T}\right)\left(\frac{b}{d}\right)^{3}\left(\frac{\sigma}{G}\right)
$$

Both Coble and Nabarro-Herring creep are useful for pure metals or solid solution alloys. Comparing the two formulas, both are linear with respect to applied stress (unlike power law creep) and are most influenced by grain sizeCoble to the third power and Nabarro-Herring to the second. Again, these formulae are only valid for steady-state creep. 
Constitutive Equation Parameters for Pure Aluminum - Table 1 defines and presents the parameters used in equations (3-7). These values were reported in reference 9 and are valid for pure aluminum. No test data are available for the creep behavior of uranium-aluminum. In this analysis, creep of the uraniumaluminum material will be simulated by assuming it behaves as pure aluminum of the appropriate mean grain diameter.

\begin{tabular}{|c|c|c|}
\hline Parameter & Description & Value \\
\hline $\mathrm{A}_{\mathrm{NH}}$ & dimensionless constant for N-H creep & 28 \\
\hline $\mathrm{A}_{\mathrm{Co}}$ & dimensionless constant for Coble creep & 66.8 \\
\hline $\mathrm{A}_{\mathrm{HD}}$ & dimensionless constant for Harper-Dorn creep & $1.67 \times 10^{-11}$ \\
\hline$A_{1}$ & dimensionless constant for power law creep & $2.5 \times 10^{6}$ \\
\hline$\overline{D_{\alpha(1)}}$ & lattice diffusion frequency factor & $1.86 \mathrm{~cm}^{2} / \mathrm{sec}$ \\
\hline $\mathrm{D}_{\mathrm{o}(\mathrm{gb})}$ & grain boundary diffusion frequency factor & $\mathrm{D}_{\mathrm{o}(1)}\left[\mathrm{cm}^{2} / \mathrm{sec}\right]$ \\
\hline$D_{o(c)}$ & core diffusion frequency factor & $\mathrm{D}_{\mathrm{o}(\mathrm{gb})}\left[\mathrm{cm}^{2} / \mathrm{sec}\right]$ \\
\hline$\overline{Q_{1}}$ & lattice diffusion activation energy & $143.4 \mathrm{~kJ} / \mathrm{mol}$ \\
\hline$\overline{\mathrm{Q}_{\mathrm{gb}}}$ & grain boundary diffusion activation energy & $0.6 \mathrm{Q} \mathrm{kJ} / \mathrm{mol}$ \\
\hline$Q_{c}$ & core diffusion activation energy & $\mathrm{Q}_{\mathrm{gb}}[\mathrm{kJ} / \mathrm{mol}]$ \\
\hline $\mathrm{T}$ & absolute temperature & $\mathrm{T}[\mathrm{K}]$ \\
\hline $\mathrm{G}$ & shear modulus at temperature $T$ & $\mathrm{G}_{0}-\Delta \mathrm{G} \cdot \mathrm{T}[\mathrm{MPa}]$ \\
\hline $\mathrm{G}_{\mathrm{o}}$ & room temperature shear modulus & $3.022 \times 10^{4} \mathrm{MPa}$ \\
\hline$\Delta \mathrm{G}$ & temperature dependent shear modulus & $16.0 \mathrm{MPa} \mathrm{K}^{-1}$ \\
\hline $\mathbf{R}$ & Gas Constant & $\begin{array}{l}8.31 \times 10^{-3} \\
\mathrm{~kJ} / \mathrm{mole} / \mathrm{K}\end{array}$ \\
\hline $\mathrm{k}$ & Boltzmann's Constant & $\begin{array}{l}1.38 \times 10^{-23} \\
\mathrm{~J} / \text { atom } / \mathrm{K}\end{array}$ \\
\hline $\mathrm{b}$ & Burger's vector & $2.86 \times 10^{-8} \mathrm{~cm}$ \\
\hline $\mathrm{n}$ & power law creep exponent & 4.4 \\
\hline $\mathrm{d}$ & average grain size & $\mathrm{d}[\mathrm{cm}]$ \\
\hline \multicolumn{3}{|c|}{$\begin{array}{l}\text { Note: - Values reported are for pure aluminum. All data from reference } 9 . \\
\text { - The units are reported per literature. They must be converted to a } \\
\text { consistent set of units for proper application. }\end{array}$} \\
\hline
\end{tabular}




\subsection{Other Material Property Data}

The other material properties used in this analysis are presented in table 2.

\begin{tabular}{|c|c|}
\hline Material & Density $\left(\mathrm{lbf} / \mathrm{in}^{\wedge} 3\right)^{1}[10]$ \\
\hline $\mathrm{Al} 1100$ & 0.0975 \\
\hline U-Al & 0.1330 \\
\hline Material & $\begin{array}{l}\text { Yield/Tensile Stress (psi)/Elongation } \\
\text { (in./in.) }{ }^{2}[11]\end{array}$ \\
\hline Al $1100\left(75^{\circ} \mathrm{F}\right)$ & $5,000 / 13,000 / 0.4$ \\
\hline Al $1100\left(212^{\circ} \mathrm{F}\right)$ & $4,600 / 10,000 / 0.45$ \\
\hline $\mathrm{Al} 1100\left(300^{\circ} \mathrm{F}\right)$ & $4,200 / 8,000 / 0.55$ \\
\hline Al $1100\left(400^{\circ} \mathrm{F}\right)$ & $3,500 / 6,000 / 0.65$ \\
\hline $\operatorname{Al} 1100\left(500^{\circ} \mathrm{F}\right)$ & $2,600 / 4,000 / 0.75$ \\
\hline Material & $\overline{\text { Elastic Modulus (psi) }{ }^{3}[11]}$ \\
\hline Al $1100\left(0^{\circ} \mathrm{F}\right)$ & $11.0 \mathrm{E} 6$ \\
\hline $\mathrm{Al} 1100\left(400^{\circ} \mathrm{F}\right)$ & $10.0 \mathrm{E} 6$ \\
\hline Al $1100\left(800^{\circ} \mathrm{F}\right)$ & $\overline{8.3 \mathrm{E} 6}$ \\
\hline Material & Thermal Expansion Coefficient ${ }^{4}[10]$ \\
\hline Al $1100\left(32^{\circ} \mathrm{F}\right)$ & $23.0 \mathrm{E}-6$ \\
\hline Al $1100\left(135^{\circ} \mathrm{F}\right)$ & $24.1 \mathrm{E}-6$ \\
\hline Al $1100\left(225^{\circ} \mathrm{F}\right)$ & $24.9 \mathrm{E}-6$ \\
\hline $\mathrm{Al} 1100\left(405^{\circ} \mathrm{F}\right)$ & $26.5 \mathrm{E}-6$ \\
\hline $\mathrm{Al} 1100\left(585^{\circ} \mathrm{F}\right)$ & $28.2 \mathrm{E}-6$ \\
\hline $\mathrm{U}-\mathrm{Al}\left(32^{\circ} \mathrm{F}\right)$ & $18.4 \mathrm{E}-6$ \\
\hline $\mathrm{U}-\mathrm{Al}\left(135^{\circ} \mathrm{F}\right)$ & $19.3 \mathrm{E}-6$ \\
\hline $\mathrm{U}-\mathrm{Al}\left(225^{\circ} \mathrm{F}\right)$ & $19.9 \mathrm{E}-6$ \\
\hline $\mathrm{U}-\mathrm{Al}\left(405^{\circ} \mathrm{F}\right)$ & $21.2 \mathrm{E}-6$ \\
\hline $\mathrm{U}-\mathrm{Al}\left(585^{\circ} \mathrm{F}\right)$ & $22.6 \mathrm{E}-6$ \\
\hline $\begin{array}{l}{ }^{1} \text { These values must } \\
{ }^{2} \text { Bilinear s-e curve a } \\
{ }^{3} \text { U-Al properties ass } \\
{ }^{4} \text { U-Al data } 20 \% \text { less }\end{array}$ & $\begin{array}{l}\operatorname{tant} 386.4 \mathrm{in} / \mathrm{sec} / \mathrm{sec} \text {. } \\
\text { ned the same as Al } 1100 . \\
\text { sson's Ratio }=0.3 \mathrm{in} \text { all cases. } \\
\text { erature range for } 30.5 \mathrm{w} \% \mathrm{U} \text { allo }\end{array}$ \\
\hline
\end{tabular}

\section{Finite Element Stress and Creep Analysis}

The stress level in a material is a strong determining factor in the overall creep level seen in the material. Creep is linearly dependent on stress level if in the diffusion regime and, for pure aluminum, can have a sixth order dependence if in the high temperature power law regime. Clearly, a reasonable understanding of the stresses in the fuel during storage 
conditions is critical to a valid estimation of creep during the storage life. With this aim, the finite element code ABAQUS was used to estimate stress levels in the fuel under anticipated conditions as described below.

\subsection{MTR Fuel Element Model Description}

Figure 1 shows the finite element model used to predict the stresses in the MTR fuel elements. The model is composed of 659 nodes and 168 laminate, 8-noded shell element for the cladded fuel portion and 28, 8-noded shell element for the solid aluminum ends. The ends of the fuel elements, approximately 0.75 inch each, are solid aluminum rather than cladded uranium-aluminum. Laminated shells were chosen due to the efficiency of shell elements for this geometry and the ability of ABAQUS to specify the shell section properties as a composite. Each layer (clad-fuel-clad) was specified to the proper thickness and each layer had five section points through the thickness where stresses are calculated at each of eight integration points. A higher mesh density was used at the end of the fuel element to capture the stress intensity effect of the material transition at that location. Material properties used in the analysis were described in section 3 and summarized in Table 2. Two symmetry planes were used for the horizontal storage state: one longitudinal and one transverse as shown in Figure 5.

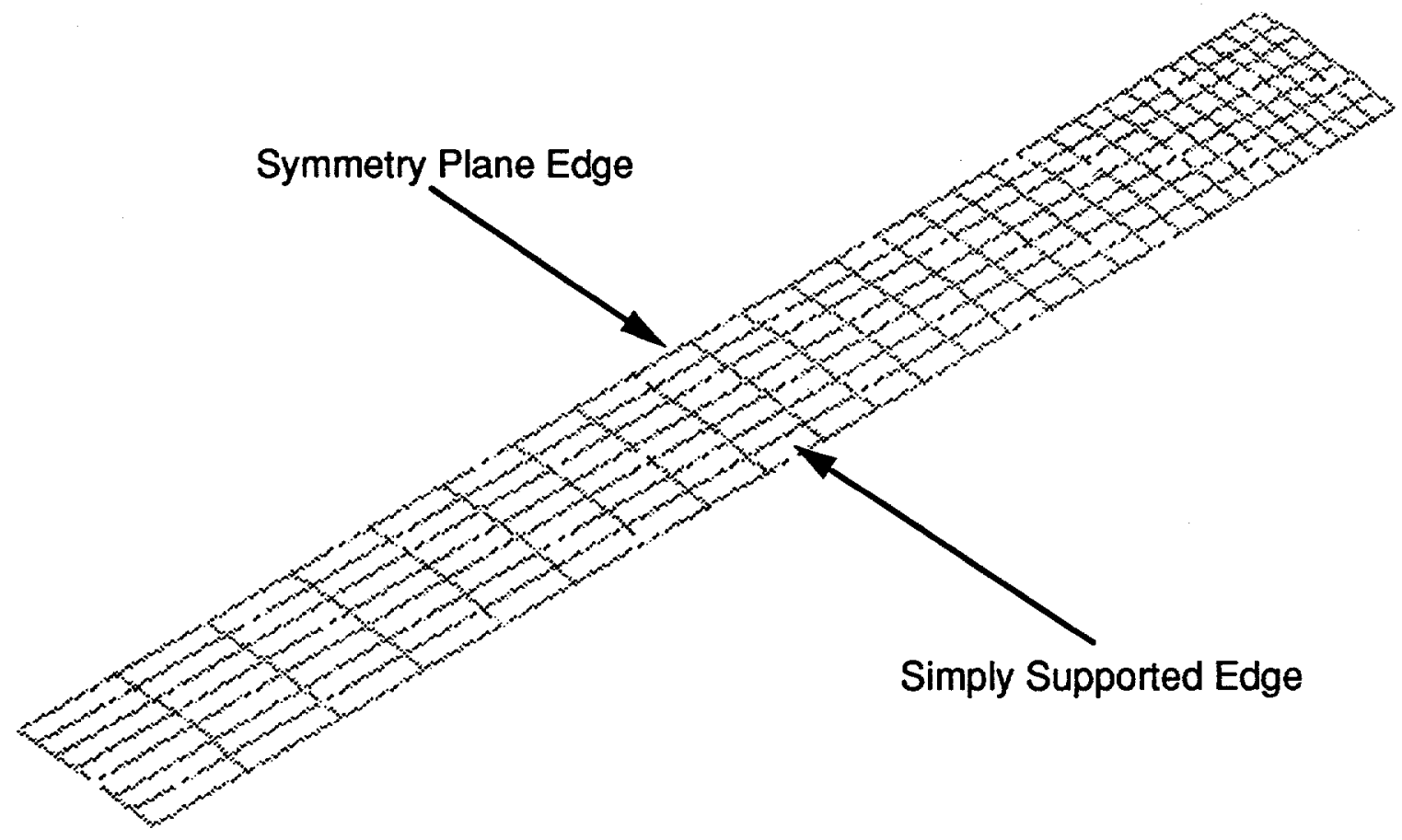

Figure 5 - Finite Element Model of MTR Fuel Element 


\subsection{Model Loading and Boundary Conditions}

The only applied loading for spent nuclear fuel in dry storage configurations is gravity. There are other sources of internal stresses to be considered such as differential thermal expansion and residual stresses. Applied loads are the only loads that are of concern for long-term creep analysis because internal stresses are self-relieving. The internal stresses cause material creep that, in turn, relieves the internal stress that drives creep. Regardless, thermally induced stresses can be very large compared to the applied stresses in this case if only for a short period of time. Thermal expansion stresses are simulated in the finite element analysis. Gravity loads were applied by simply applying the acceleration of gravity to the model in one step. Three storage configurations were examined, two horizontal and one vertical .

Some discussion of boundary conditions is required due to the effect on stress levels. The engineering drawing of the fuel assemblies shows that the edges of the fuel elements (fuel plates) slide into milled slots in the side support plates. It is unclear how tightly the fuel elements are constrained by the side plates especially considering thermal expansion and possible creep over time. The two bounding cases are: simply supported fuel elements (no moment resistance or lateral support-only vertical), and built-in or fixed (no rotation or translation). The added support in the built-in configuration will result in reduced stresses in the fuel elements compared to maximum bounding stresses due to the increased bending under simply supported boundary conditions. Both of these conditions were examined. Also, local maximum stresses due to imperfections in geometry, material etc. will result in potentially locally higher stresses than reported here. These local stresses, however, will have a minimal effect on the global creep behavior of the fuel elements that will drive the overall deformation of the structure.

\subsection{Finite Element Analysis Results}

The maximum applied stress on a fuel element occurred under horizontal storage with the simply supported boundary condition for the edges of the plate. In this configuration, bending stresses due to gravity lead to peak stress levels on the outside surfaces of the plate. The peak von Mises stress was found to be 13.1 psi [12]. The mean stress throughout the fuel element is $4.4 \mathrm{psi}$. Under fixed edge boundary conditions, peak and mean stress values of 1.1 and 0.5 psi were calculated [13]. The stress levels were nearly identical for assemblies stored with the convex side of the fuel element up or down.

By consulting the deformation mechanism map of figure 3 at a normalized shear stress of $1.12 \times 10^{-6}\left(\mathrm{~s}=4.4 \mathrm{psi}, \mathrm{G}=3.94 \times 10^{6} \mathrm{psi}\right)$ and a homologous temperature of $0.52\left(200^{\circ} \mathrm{C}\right)$, it is readily observed that Coble creep is the dominant mechanism. The " $\mathrm{X}$ " on figure 3 marks this condition but note that figure 3 is for a mean grain diameter of $10 \mu \mathrm{m}$ so for other grain sizes direct, graphical interpretation is not advisable. 
ABAQUS has a standard power law creep model as described be equation 8 where a stress/creep simulation can be run simultaneously. For a given temperature and grain size, Coble creep can be reduced to this form be setting the stress exponent, $n$, to " 1 " , $t$ to " 0 " and calculating the coefficient "A" from the remaining Coble creep model parameters. ABAQUS also has the capability of incorporating a user defined creep model directly into the finite element analysis via FORTRAN programming. The former method was used in all cases for this analysis.

$$
\dot{\bar{\varepsilon}}_{\mathrm{c}}=A \sigma^{\mathrm{n}} \mathrm{t}^{\mathrm{m}}
$$

$$
\text { Where: } \begin{array}{ll}
\dot{\bar{\varepsilon}}_{\mathrm{c}}=\text { uniaxial equivalent creep strain rate } \\
\mathrm{A}, \mathrm{n}, \mathrm{m}=\text { material and temperature dependent constants } \\
\sigma=\text { equivalent stress } \\
\mathrm{t}=\text { time (time hardening power law formulation) } \\
\text { or } \quad \begin{array}{l}
t=\left(\frac{m+1}{A} \cdot \frac{\varepsilon_{c}}{\sigma^{n}}\right) \frac{1}{(m+1)} \text { (strain hardening power law } \\
\text { formulation) }
\end{array}
\end{array}
$$

\subsection{Creep and Deformation Estimate for MTR Fuel}

Twelve separate cases were simulated by varying the cladding grain size and temperature and monitoring maximum deflection and creep strain in the fuel element [14]. The first step involved applying gravity loading to the fuel element. In the next quasi-static step, the temperature of the entire assembly was raised from room temperature to the desired simulation temperature. Due to differential thermal expansion between the cladding and the core material, internal stresses as high as several thousand psi were calculated. The fuel elements were assumed to be initially stress free before the application of gravity loading. The final step was to allow the material to creep in a visco-elastic step for a fifty year simulation period. In all cases, the large internal stresses due to differential thermal expansion are predicted to rapidly converge to the gravity stresses alone within approximately one month of exposure.

A major assumption in this analysis is that the uranium-aluminum core material exhibits creep behavior similar to the aluminum cladding material. Micrographs of material similar to the MTR fuel element cores show that aluminum and aluminide particles exist that are on the order of $15 \mu \mathrm{m}$ in diameter together with the eutectic regions [10]. Within these eutectic regions, laminate structures are present that, all told, result in far more boundary surface area than just for grain boundaries in solid phase solutions. This is a concern because the increase in boundary surface area increases the opportunity for boundary diffusion-the dominant creep mechanism under dry storage conditions. 
It is not clear how the multi-phase, laminar structure of the core material will behave under creep conditions, however, analysis has shown the overall creep behavior of the entire fuel plate is not sensitive to the intrinsic creep behavior of the core material. The finite element analyses show that the deformation of the fuel plates is dominated by the creep response of the cladding material. This is due to the relative diffusion creep resistance of the large grained cladding material that tends to constrain the creep of the core material. By varying the assumed grain size of the core material-hence increasing or decreasing the creep strain rate-only very slight differences in fuel plate deformation were calculated for any given cladding grain size. The importance of this finding is that the creep response of the fuel plates can be predicted based on the characteristics of the aluminum cladding material rather than the undetermined core material characteristics (e. g. creep behavior, grain size, etc.)

A proposed maximum allowable deflection for MTR fuel due to creep strain is 0.1 inch. This value is based on the approximate spacing between fuel plates and would ensure that fuel plates do not touch one another and that large creep strains do not occur that could lead to creep rupture. Figure 6 parametrically shows the results of the finite element creep analysis. For the proposed 0.1 inch limit to peak deflection of a fuel element from creep deformation, the limiting fuel temperature will be from approximately $150^{\circ} \mathrm{C}$ to $250^{\circ} \mathrm{C}$ for cladding grain sizes of $25 \mu \mathrm{m}$ to $100 \mu \mathrm{m}$, respectively. Figure 7 shows two optical micrographs representing the range of grain sizes in MTR fuel cladding [15]. The elongated grains were formed during fabrication by hot rolling. The minimum grain dimension shown in micrographs is approximately $50 \mu \mathrm{m}$. Using this as the effective diameter in the creep deformation analysis results in a limiting fuel temperature of $200^{\circ} \mathrm{C}$.

Based on this analysis with its conservative modeling assumptions, a fuel temperature limit for MTR fuel in dry storage of $200^{\circ} \mathrm{C}$ provides high assurance that significant creep deformation would not occur in 50 years.

\section{Comparison to a Similar Creep Analysis}

Recent work on the ATR fuel, which is similar to the MTR fuel, was performed at INEL [17]. The initial approach of this present analysis was to apply directly this work including creep model development and stress simulation to the MTR fuel design. Faced with the same problem of how best to model the fuel assemblies and extrapolate literature creep data to low applied stress regimes, SRS chose a complimentary approach. In this section the INEL analysis is summarized and compared to the present analysis. 


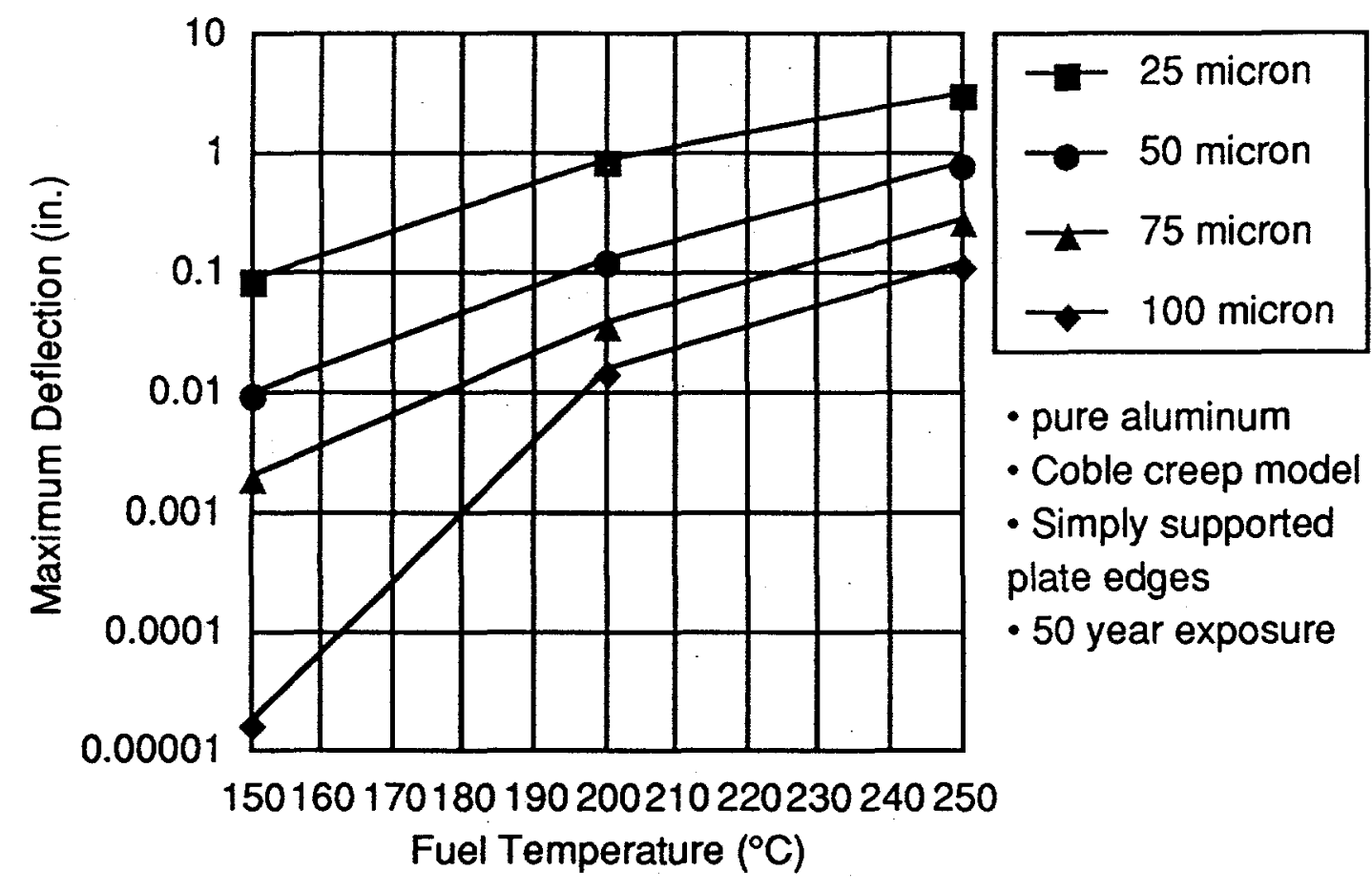

Figure 6 - Maximum Deflection vs. Fuel Temperature

\subsection{Creep Data and Fuel Element Model for an ATR Fuel Element}

Reference 16, an EG\&G, INEL report, documents an analysis to predict long-term creep deformation of ATR fuel elements under dry storage conditions. The ATR fuel elements share many physical characteristics of the MTR fuel that will be the dominant configuration of spent fuel to be stored at SRS thereby making the results useful for the present analysis. A considerable amount of detail was presented regarding the development of the creep model from literature data because there is a lack of data in the low-stress, low-temperature regime. The finite element code ABAQUS was used to estimate the stresses in the ATR fuel and calculate the creep over a fifty year period.

A 3D finite element model of a single fuel element was used in the stress/creep analysis. Solid, eight-node elements were used with three through the plate thickness. Homogenous material properties for aluminum were used except for material density, which was adjusted to reflect the aluminum/uraniumaluminum constitution. One longitudinal symmetry plane was assumed with clamped plate edges. Under gravity loading, the maximum stress reported was $0.3 \mathrm{psi}$. This occurred with fuel elements in the horizontal position. Plates under gravity load in the vertical position was also examined and the stress was found to be less.

Several models to fit the creep data for Al 6061 generated by ORNL [17], including a "bounding-case" creep model for low-stress applications were developed. Figure 8 shows a reproduction of the $250^{\circ} \mathrm{C}$ creep data. 

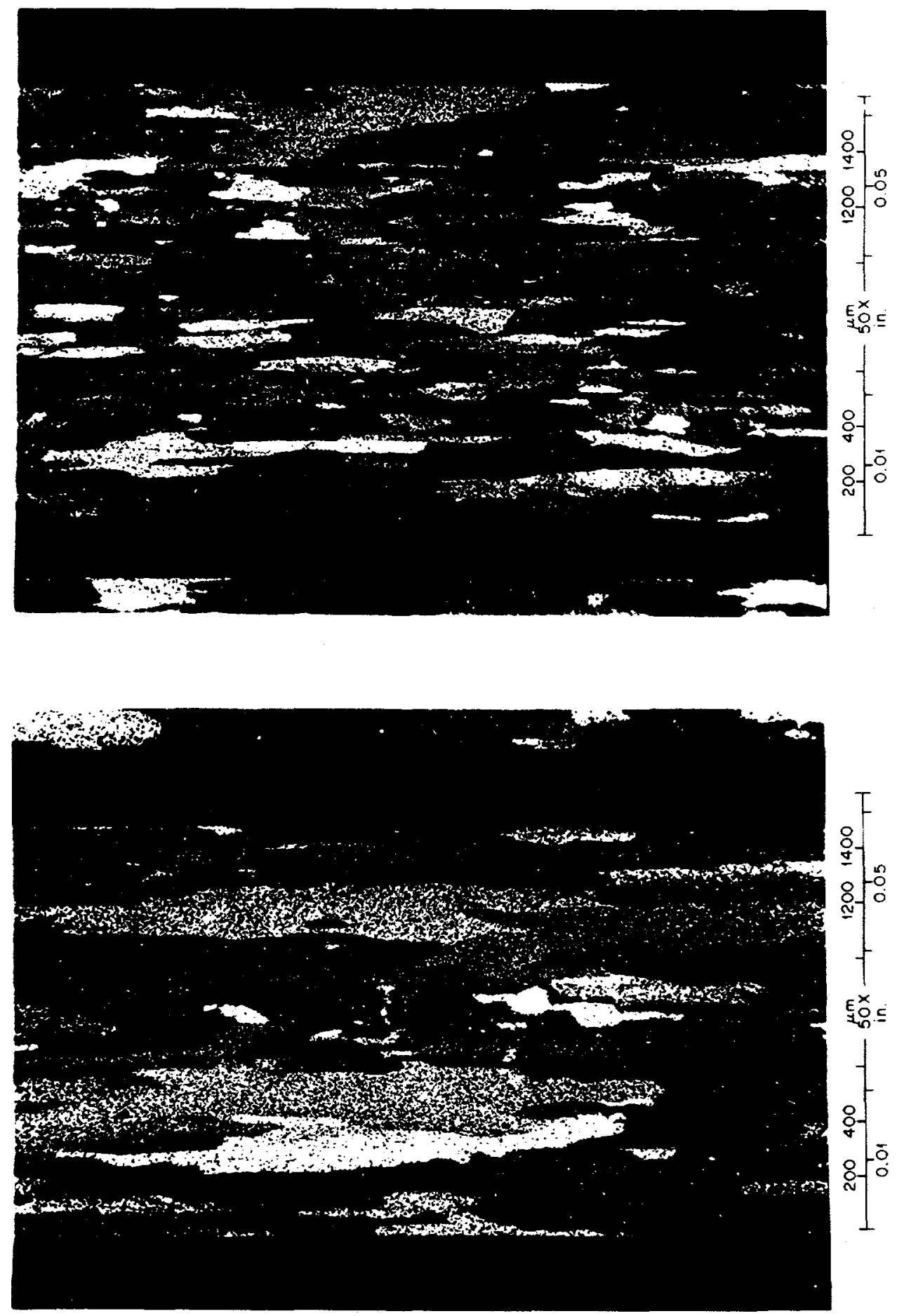

Figure 7 - Optical Micrographs of MTR Fuel Cladding Cross-Section 
The report [16] details the derivation of several possible models from literature data in the form of equation 8 for implementation into an ABAQUS finite element analysis. Among the several stress-dependent creep models, a lowstress model was constructed by extrapolation to applied stress of approximately 1 psi-equation $9 \mathrm{a}$, the resulting best fit. Citing the large degree of uncertainty in the creep models, equation $9 \mathrm{~b}$ was suggested as an upper bound model.

$$
\begin{aligned}
& \varepsilon_{c}=4.65 \times 10^{-21} \sigma^{4.37} t^{0.76} \\
& \varepsilon_{c}=2.23 \times 10^{-6} \sigma^{0.5} t^{0.75}
\end{aligned}
$$

In order to be implemented in the ABAQUS finite element analysis, equation $9 b$ was differentiated with respect to " $\mathrm{t}$ " to yield:

$$
\dot{\varepsilon}_{c}=1.67 \times 10^{-6} \sigma^{0.5} t^{-0.25}
$$

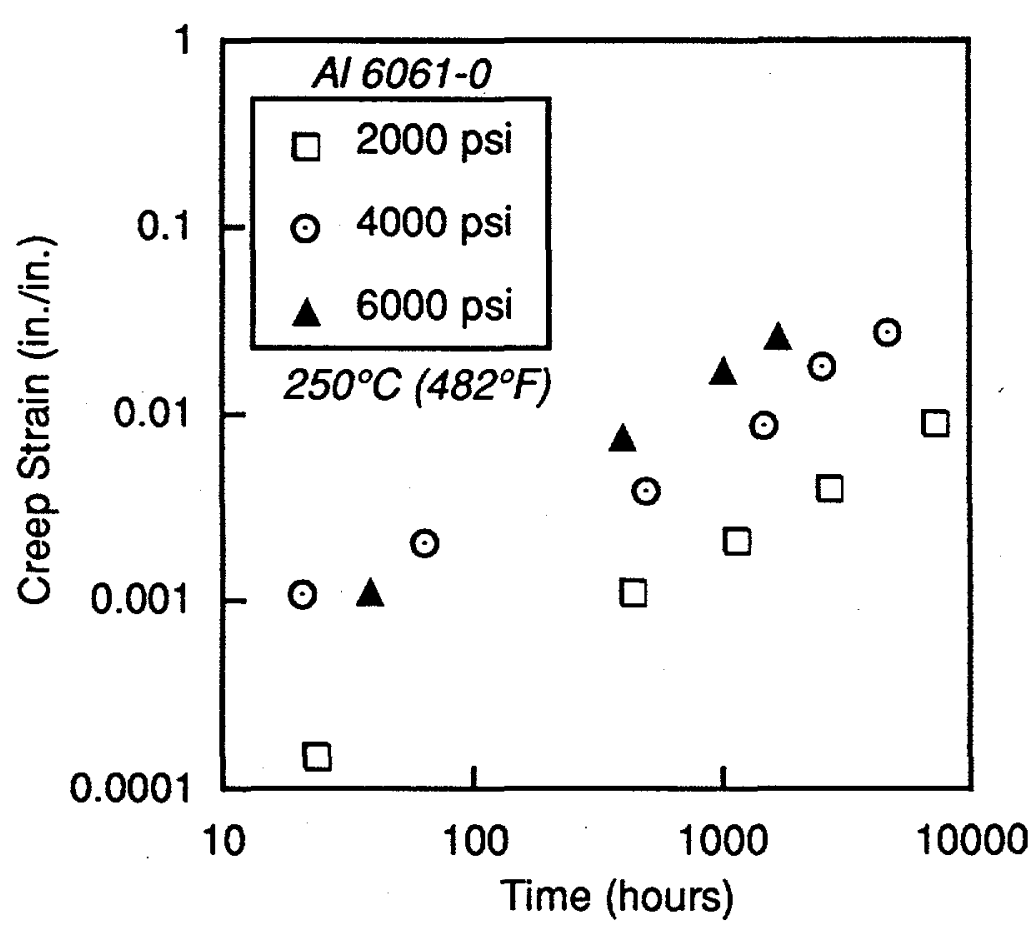

Figure 8 - ORNL Creep Data for $\mathrm{Al} 6061-0$ at $250^{\circ} \mathrm{C}\left(482^{\circ} \mathrm{F}\right)$ [17]

The fuel model was analyzed both assuming horizontal and vertical storage. The stress results showed that $0.3 \mathrm{psi}$ is the maximum stress in the fuel element during vertical storage conditions resulting in a creep strain of about $3.3 \%$ and a 0.03 to 0.04 inch displacement of the center of gravity at $250^{\circ} \mathrm{C}$ over a 100 year time span. The horizontal storage condition resulted in a 0.1 psi maximum stress and a final creep strain of $1.9 \%$ and a center of gravity displacement of 0.006 inch. 
In summary, the following are the differences between the analysis for an ATR element (Ref. 16) and the present analysis. Although the detailed approaches of the two analyses was quite different, the conclusions reached are similar with respect to the limiting temperature for dry fuel storage based on creep deformation.

- The ATR fuel element analysis used a power law creep model to span both the primary and steady-state creep regimes. The predominant steady-state deformation process for low-stress conditions is grain boundary diffusion, modeled as Coble creep with a strong grain size dependency and a linear dependence on stress. The Coble creep model was used in the present analysis.

- Other sources of stress - The applied stress in the INEL analysis ranged from 0.1 to 0.3 psi. Qualitatively, this is an extremely small stress that is certainly much less than the uncertainty on stress in the analysis. Residual stresses, differential thermal expansion and physical constraints almost certainly result in internal stresses larger than fractions of a psi. The fixed boundary conditions assumed are potentially non-conservative as the support from the side plates constrains the fuel plate and mitigates bending of the plates. Simply supported boundary conditions are a bounding condition.

- Mesh resolution - No mention of a mesh convergence study was mentioned in the report. While three, first-order elements through the fuel element thickness is minimally adequate to calculate elastic bending stresses, it is not possible to capture the peak bending stresses that occur on the outer surfaces. Reduced integration elements calculate stresses at the element centroid rather than the outer surface such like shell elements.

\section{Application of Coble Creep Model to Experimental Data}

The wealth of literature test data for creep of aluminum is almost exclusively at higher stress levels, or higher temperature or both compared to dry storage conditions. One exception that provides a valuable check on the analytical approach undertaken here is found in reference 18. Among other conditions, test data is reported at $250^{\circ} \mathrm{C}$ and 200 psi applied stress for up to 3,200 hours. The grain size was reported to be $0.09 \mathrm{~mm}(90 \mu \mathrm{m})$. The deformation mechanism map predicts that Coble creep will be the dominant creep mechanism for these conditions as it is for dry storage of MTR fuel. Table 3 shows the test results and the creep estimate by equation 7 that was used to predict creep in the MTR fuel. The analytical creep model conservatively overpredicts the measured creep strain by a factor of 3-4 over the 3200 hour time period. 


\begin{tabular}{|c|c|c|}
\hline \multicolumn{3}{|c|}{ Table 3 - Comparison of Coble Creep Model to Experimental Data } \\
\hline & \multicolumn{2}{|c|}{ Coble Creep of Pure Aluminum } \\
\hline Time (hr) & Test Results (\%) ${ }^{\mathbf{1}}$ & Analytical Results (\%) \\
\hline 200 & 0.00 & 0.00 \\
\hline 500 & 0.00 & 0.01 \\
\hline 1000 & 0.005 & 0.02 \\
\hline 2000 & 0.01 & 0.04 \\
\hline 3000 & 0.02 & 0.06 \\
\hline 3200 & 0.02 & 0.06 \\
\hline $\begin{array}{l}1 \\
\text { 1 Values as reported in reference } 16 \text { are total extension that includes elastic strain. } 0.02 \text { inch was } \\
\text { subtracted from the reported values as an estimate of elastic strain and reported here to provide a direct } \\
\text { 20mparison to the analytical results. }\end{array}$ \\
\hline
\end{tabular}

\section{Acknowledgment}

The authors wish to acknowledge W. L. Daugherty for insightful discussions on material creep and H. B. Peacock for providing essential data.

\section{References}

[1] Matos, J. E., "Foreign Research Reactor Spent Nuclear Fuel Inventories Containing HEU and LEU of US-Origin," Proceedings of DOE Spent Nuclear Fuel-Challenges \& Initiatives, American Nuclear Society, December 13-16, 1994.

[2] INEL Programmatic Environmental Impact Statement

[3] Sindelar, R. L., H. B. Peacock, "Plan for Development of Acceptance Criteria for Interim Dry Storage of Al-Clad Spent Nuclear Fuel (U)," WSRC-RP-94-360, Rev. 1, February 1995.

[4] Sindelar, R. L., H. N. Guerrero, "RE: SRS Demonstration Dry Storage Facility - Performance Requirements and Specifications for a Fuel Storage System (U)," SRT-ETF-950022/SRT-MTS-95-2009, Febuary 28, 1995.

[5] Drawing \# 409337, "University of Virginia Test Research and Training Reactor 2 fuel plate," 10/13/80, EG\&G Idaho Inc. 
[6] Cadek, J., Creep in Metallic Materials, Elsevier Science Publishing Company Inc., 1988.

[7] Callister, W. D Jr., Materials Science and Engineering, John D. Wiley \& Sons, 1985.

[8] Frost, H. J., M. F. Ashby, Deformation Mechanisms: The Plasticity and Creep of Metals and Ceramics, Permagon Press, 1982.

[9] Langdon, T. G., F. A. Mohamed, "A New Type of Deformation Mechanism Map for High-temperature Creep," Materials Science and Engineering, 32 (1978) $103-112$.

[10] Snelgrove, J. L., G. L. Hofman, R. L. Frontroth, W. R. McDonell, H. B. Peacock, R. F. Whitacre, G. L. Copeland, "Evaluation of Existing Technology Base for Candidate Fuels and Target Materials for the HWRNPR," ANL/NPR-90/008, March 1990.

[11] Davis, J. R., ASM Specialty Handbook, ASM International, 1990.

[12] Computer files, afs/srtc.srs.gov/u1/12280/projects/dryfuel/mtrsh1.*, Finite element analysis: simply-supported case, 3/3/95.

[13] Computer files, afs/srtc.srs.gov/u1/12280/projects/dryfuel/mtrsh2.*, Finite element analysis: built-in case, 3/3/95.

[14] Computer files, afs/srtc.srs.gov/u1/12280/project1/dryfuel/mtr\#_\#.*, Finite element analyses (12): \# means "grain size" _temperature".

[15] Private communication: G. L. Copeland to H. B. Peacock, 3/21/95.

[16] Lacy, J. M., "Long Term Creep Deformation of ATR Fuel Elements Under Dry Storage Conditions," B460-94-082, EG\&G Idaho Inc., August 15, 1994.

[17] Martin, W. R., J. R. Weir, "Mechanical Properties of X-8001 and 6061 Aluminum Alloys and Aluminum Based Fuel Dispersion at Elevated Temperatures," ORNL 3557, UC-25-Metals, Ceramics, and Materials, TID4500, February 1964.

[18] McKeown, J., R. Eborall, R. D. S. Lushey, "The Creep Properties of $99.8 \%$ Purity Aluminum at $20-80^{\circ} \mathrm{C}$ and at $250^{\circ} \mathrm{C}$ and $450^{\circ} \mathrm{C}$," Metallurgia, July 1954, pp. 13-15. 
DOCUMENT: $\quad$ WSRC-TR-95-0121

TITLE:

CREEP ANALYSIS FOR MATERIALS TEST REACTOR (MTR) FUEL ASSEMBLIES IN DRY STORAGE (U)

\author{
DISTRIBUTION:
}

J. R. MURPHY, 707-C

E. R. CONATSER, 707-C

M. E. DUPONT, 707-C

N. C. IYER, 773-A

M. R. LOUTHAN, 773-A

J. P. HOWELL, 773-41A

T. L. CAPELETTI, 773-41A

D. R. MUHLBAIER, 786-5A

H. N. GUERRERO, 786-5A

J. D. COHEN, 773-A

P. S. LAM, 773-42A

H. B. PEACOCK, 773-A

W. L. DAUGHERTY, 730-A

R. F. MILLER, 773-41A

R. L. SINDELAR, 773-41A 